\title{
SLIČNOSTI I RAZLIKE ŠUVAROVE I BOLONJSKE REFORME OBRAZOVANJA ${ }^{1}$
}

\author{
Maja Bosanac, istraživač suradnik \\ Filozofski fakultet u Novom Sadu \\ Adresa: Dr Zorana Đinđića 2, Novi Sad, Republika Srbija \\ Telefon: 00381649309637, e-mail: maja.bosanac@ff.uns.ac.rs \\ Radovan Grandić, redovni profesor u mirovini \\ Filozofski fakultet u Novom Sadu \\ Adresa: Dr Zorana Đinđića 2, Novi Sad, Republika Srbija \\ Telefon: 0038163507398,e-mail: grandic@neobee.net
}

\section{SAŽETAK}

Odgoj i obrazovanje oduvijek su neraskidivo povezani s društvenim, ekonomskim, političkim i kulturnim događajima. Cilj rada je razmotriti osnovne sličnosti i razlike između bolonjske i Šuvarove reforme obrazovanja. lako je bolonjska reforma usmjerena na visoko obrazovanje, a Šuvarova se reforma prvenstveno odnosila na srednjoškolsko obrazovanje te reforme također sadrže brojne sličnosti čije bi implikacije mogle biti važne za cjelovitije razumijevanje brojnih očekivanja koja postavljaju moderne obrazovne ustanove. Jedna od osnovnih sličnosti obje reforme je povezanost obrazovanja sa svijetom rada i zahtjevima tržišta. Upravo je ta karakteristika modernih zahtjeva za odgojem obrazovanja istovremeno najkontroverznija $i$ često kritizirana. Doprinos ovog rada podrazumijeva aktualizaciju pitanja Šuvarove reforme koja se često uspoređuje s bolonjskim procesom. U zaključku rada ističe se da bez obzira na razlike, čija je jedna od osnovnih činjenica da je Šuvarova reforma napuštena za razliku od trenutne bolonjske, usporedba ovih reformi može biti važna posebno kada je riječ o razumijevanju društveno-ekonomskih i političkih utjecaja na proces obrazovanja.

Ključne riječi: reforma obrazovanja; bolonjski proces; Šuvarova reforma; usmjereno obrazovanje; tržište

\footnotetext{
1 Rad je nastao u okviru projekta: Pedagoški pluralizam kao osnova strategije obrazovanja (179036) koji financira Ministarstvo prosvete, nauke i tehnološkog razvoja.
} 


\section{UVOD}

Nakon što se pedagogija diferencirala od filozofije, postavilo se pitanje njezinog odnosa s drugim znanostima. Danas je općeprihvaćena činjenica da granične discipline, kao i međusobna povezanost znanosti predstavljaju dodatno obogaćivanje svih znanosti, a suradnja se stalno treba proširivati i produbljivati (Grandić, 2007). Nemoguće je proučavati pedagogiju kao znanost bez poznavanja osnovnih filozofskih, psiholoških i antropoloških osnova koje nude odgovore na pitanja o čovjeku, njegovoj prirodi. Međutim, socijalni kontekst je od posebnog značaja, posebno u razdoblju kada vanjski društveno-ekonomski utjecaji sve više prodiru u obrazovni proces na svim razinama. U tom je kontekstu pedagogija povezana i sa sociologijom i ekonomijom. U suvremenom obrazovnom kontekstu pedagogija se odmiče sve dalje i dalje od filozofskih osnova i približava se ekonomskim, što dodatno utječe na činjenicu da moderno obrazovanje postaje meta kritike, što utječe i na brojne zahtjeve za redefiniranjem obrazovnih ciljeva, ali i zahtjevima za sveobuhvatnim obrazovnim reformama.

S jedne strane, kritičari ističu da obrazovne institucije ne pripremaju dovoljno za svijet rada, dok s druge strane, nije mali broj predstavnika koji ističu zabrinutost zbog sociohumanističke dimenzije obrazovanja. U tom kontekstu, Milan Uzelac (2007) također naglašava brigu za moderna sveučilišta i obrazovanje općenito, pozivajući se na Aristotelovu trorazinsku podjelu znanja na poetička, praktična i teorijska. Milutinović (2008) naglašava da znanje promatrano kao koncept potječe iz razdoblja antičke Grčke i Aristotela koji su jasno razlikovali tri vrste ljudskog života i aktivnosti. To su: theoria, praxis i poesis. Teorija je označavala spekulativni život, u kojem se istina tražila isključivo kroz proces razmišljanja; praxis je značio praktični život, koji je opisan kao reflektirajući angažman u nekom području društva, odnosno praksa je uključivala djelovanje i refleksiju, dok je poesis označavao produktivni život, stvaranje artefakata i konkretnih predmeta. Teorija je imala veću vrijednost u odnosu na praksu, jer se smatralo da ono što se uči iz iskustva ima nižu vrijednost u odnosu na ono što je pružila teorija. Međutim, kao posljedica brojnih kritika da se suvremeno obrazovanje previše odvaja od života i ne priprema za svijet rada, sve se više naglašava važnost iskustvenog učenja, kao i sve izraženija društvena dimenzija obrazovanja.

Jedna od reformi srednjoškolskog obrazovanja koja se često kritizira kao pokušaj uništavanja humanističkog duha obrazovanja jest Šuvarova reforma, koja više nije aktualna, ali sve veći broj kritičara modernog obrazovanja slaže se da Šuvarova reforma sadrži mnogo sličnosti s trenutnom i jednako kritiziranom bolonjskom reformom obrazovanja. Šuvarova reforma može poslužiti kao dobar okvir za analizu moderne reforme visokog obrazovanja i njegovih društveno-ekonomskih i političkih okolnosti koje utječu na suvremeni, novi model obrazovanja u okviru bolonjskog procesa koji se promatra kao redukcionistički u smislu svođenja čovjeka na homo economicus-a (Uzelac, 2007).

U nastavku rada iznesena je svaka od reformi, kao i njihove osnovne sličnosti i razlike. Doprinos rada očituje se u aktualizaciji pitanja Šuvarove reforme koja se uspoređuje s bolonjskim procesom. Zajedničko za obje obrazovne reforme jest činjenica da su provedene promjene u obrazovnim sustavima za poboljšanje društva. Motivacija za pisanje rada na ovu temu proizlazi iz činjenice da su te dvije reforme povezane u medijima $u$ kojima su intervjuirani istaknuti znanstvenici, a među njima i brojni pedagozi. Tako se u novinskom članku naslova „Zazivajući Šuvara: kako je njegova reforma postala relevantna 
danas" (Lilek, 2018.) ističe da je Šuvar uveo model školovanja za potrebe gospodarstva, a današnji reformatori traže nešto slično. Članak u Politici naslovljen „Bolonja“, kao „šuvarica" (Dimitrijević, 2009) ukazuje na to da je šuvarica nastojala ukinuti elitne slojeve u socijalističkom društvu i afirmaciju proizvodnih i uslužnih zanimanja za tada udruženi rad (Lilek, 2018). Proučavanje Šuvarove obrazovne reforme može poslužiti kao dobar analitički okvir za usporedbu obrazovnih reformi, konkretno u ovom slučaju u kontekstu analitičkog i kritičkog pristupa bolonjskoj reformi obrazovanja. S jedne strane, neuspješna Šuvarova reforma može se prenijeti na modernu bolonjsku reformu i spriječiti njezin neuspjeh. Međutim, s druge strane, oživljavanje Šuvarove reforme u sličnom obliku ukazuje na rastuću važnost i relevantnost ove teme, odnosno na važnost bavljenja temom odnosa pedagogije s ekonomikom i sociologijom. U tom konteksu ističe se značaj bavljenja tematikom obrazovnog poduzetništva na način koji ekonomiju vraća među humanističke i društvene nauke, umjesto zasnivanja na neoliberalnom kapitalizmu (Pejanović, 2019).

\section{REFORMA OBRAZOVANJA}

U cilju sveobuhvatnijeg pristupa Šuvarovoj i bolonjskoj reformi obrazovanja, potrebno je naglasiti važnost i ograničenja reformi obrazovanja. U tom kontekstu, Rončević i Rafajac (2010) ističu da efekti prethodne reforme ne mogu uvijek biti u potpunosti utvrđeni, kao ni efekti svih prethodnih reformi. Unutar procesa globalizacije usvojen je niz rezolucija i provedba akata vezanih uz obrazovni sustav. Isti autori ističu da se u neprekinutom lancu reformi ova aktualna fokusira na visoko obrazovanje koje je kritizirano zbog inercije, odnosno tradicionalizma. Neki aspekti ideja koje stoje iza nove reforme mogu naći svoju osnovu u prethodnim reformama.

„Bum“ i „kriza“ obrazovanja predstavljeni su kao značajna i aktualna tema, tema o kojoj piše Šuvar (1977), naglašavajući da postoji sve više međunarodnih ekspertiza i mjera za potporu „procvatu“ i za prevladavanje krize. Misli idu u smjeru dijagnosticiranja nemoći škole i da se izvor krize traži prije svega u pedagoškoj funkciji koja nije sposobna slijediti zahtjeve i potrebe znanstvene i tehnološke revolucije kao takve, potrebe društva i slično. Stoga se traže rješenja u reformi obrazovanja i institucionalnim promjenama. U tom okviru postoje brojne sličnosti između bolonjske i Šuvarove reforme, koje se temelje na stavu da su one bile izazvane socijalno-ekonomskim i političkim pritiscima, a ne zahtjevima predstavnika akademske zajednice. Slično tome, Milutinović (2008) ističe da razvoj obrazovanja u najširem smislu danas nije toliko potaknut njegovom unutarnjom dinamikom razvoja kao što je to bio slučaj u prošlosti, već je postao mnogo osjetljiviji na vanjske pritiske.

Promjene koje je donio Bolonjski proces otvaraju pitanja koja zahtjevaju posebno istraživanje. U tom kontekstu Bodroški Spariosu (2015) u zaključnim razmatranjima moderne obrazovne reforme postavlja sljedeća pitanja: kako „hodati po žici“ u sustavu u kojem, s jedne strane, zahtjeva diverzifikaciju misija, programa, tečajeva i s druge međunarodne ekvivalencije u smislu diploma, poduke i kvalitete obrazovanja? Postoje li dokazi da je tzv. jedinstveni sustav, u usporedbi s binarnim, jamči veću raznolikost visokoškolskog obrazovanja? Ista autorica ističe važnost preispitivanja svih aspekata ekonomske instrumentalizacije sveučilišnog obrazovanja, jer se prednosti sveučilišnog obrazovanja ne mjere samo u dolarima i centima, pedagoški postupak u osnovi nije sličan poslovnom niti njegovi sudionici imaju računicu poslovnog čovjeka. 


\section{ODNOS ŠUVAROVE I BOLONJSKE REFORME OBRAZOVANJA}

Da bismo imali sveobuhvatan pristup Šuvarovoj reformi obrazovanja, važno je poznavati osnovne podatke o sociologu Stipi Šuvaru (1936.-2004.) koji je utemeljio i oblikovao sociologiju sela, kako u institucionalnom, tako i u programskom formatu (Pilić, 2005: 225). Također, Šuvar je bio ministar obrazovanja i kulture od 1974. do 1982., smatrajući da je koncept reforme koji je provodio dobar i da se uklapa u tadašnji svjetski trend, kao i da će opet postati relevantan (Lilek, 2018). U kontekstu proučavanja sličnosti i razlika između Šuvarove i trenutne bolonjske reforme obrazovanja, važno je naglasiti uvjerenje Šuvara da znanost i njezina primjena mogu doprinijeti razvoju društva u cjelini, ali i sela. lako postoji kritika na sve veću uvjetovanost znanja u kontekstu primjene, a sve manje stvaranja znanja koje je samo po sebi cilj, stvaranje novih modela proizvodnje znanja ukazuje na sve veću aktualizaciju ovog fenomena u okviru istraživanja o kontekstualno senzitivnoj znanosti (Gibbons, 2000) koja je usmjerena na prijelaz iz proizvodnje znanja iz tzv. Modela 1, koji regulira akademska zajednica i njegovih mehanizama, na proizvodnju Model-a 2, koji se provodi u kontekstu primjene i rješavanja problema u zajednici, umjesto da znanje predstavlja samo sebi svrhu (prema: Grandić i Bosanac, 2019). Dakle, Model 2 postao je dio politike, kulture, tržišta i znanosti i društva, što utječe na činjenicu da su znanost i društvo transgresivne arene koje se miješaju i podliježu trendovima koevolucije (Gibbons, 2000).

Uz znanstveno-istraživački rad, Šuvar (vodio je brojna empirijska istraživanja i istraživačke timove; uredio je četiri znanstvena časopisa) je ostao upamćen i po svom javnom radu (Pilić, 2005: 225). Međutim, njegova je reforma u cjelini imala veći broj kritičara nego pristaša. Međutim, istaknuti pedagozi poput Pastovića, iako nisu bili pristaše Šuvarove reforme, ističu i neke dobre elemente Šuvarove reforme, poput proširenja osnovnog obrazovanja, za koje Pastuović ističe da je najzdraviji dio reforme (Lilek, 2018). Također, mnogi se pedagozi slažu da se Šuvarova reforma oslanjala na skandinavski koncept koji i dalje smatraju poželjnim (Lilek, 2018).

Da bismo razumjeli kontekst reforme obrazovanja iz 1974., važno je naglasiti da je ovo razdoblje postojanja Jugoslavije u kojem je naglašena ambicija da to bude samoupravni koncept u kojem će ljudi iz materijalne proizvodnje imati daleko veći utjecaj ne samo na financiranje, već i na izražavanje potreba za osobljem, utjecaj na obrazovnu politiku, na tijela obrazovnog sustava, na nastavne programe škola i fakulteta, a samim time i obvezu zapošljavanja onih koji ih završavaju (Grandić, 2007: 36). Kao što isti autor naglašava, koncept se temeljio na nekoliko načela:

(a) uspostavlja se besplatna razmjena između rada škola, fakulteta i gospodarstva, koja je morala biti izravna kada određena škola, fakultet zaključi ugovor i neizravnu gdje se kontakti između gospodarstva i obrazovanja ostvaruju putem SIZ-a,

(b) uvođenje marksizma kao obveznog predmeta u škole te kasnije otvaranje posebne studijske skupine na fakultetu,

(c) sve se razine i oblici obrazovanja nakon osnovne škole trebaju istovremeno pripremati za rad i za nastavak obrazovanja (obrazovanje uz rad, iz rada i prije rada) (Grandić, 2007: 36). 
U tom su razdoblju ukinute gimnazije i stvorene su jedinstvene srednje škole. Ova vrsta usmjerenog obrazovanja povezana je sa Stipom Šuvarom kao jednim od inicijatora, stvaraoca i aktivnih zagovornika ove reforme (Jarić, 2012). Šuvar je podijelio strukturu nove srednje škole na pripremnu i usmjerenu fazu školovanja za određena zanimanja. Prema Šuvaru, zajednička faza usmjerenog obrazovanja, koja uključuje prve dvije godine srednje škole, trebala je pružiti cijeloj mladoj generaciji ne samo zadovoljavajuću, već i jednaku opću kulturu i na taj način pružiti osnovu za kasniju i maksimalnu mobilnost u području strukovnog obrazovanja, kao i da omogući selekciju prema sposobnostima, a ne prema nasljednim okolnostima. Škole - i kasnije gimnazije - pridružile su se velikim obrazovnim centrima radi uključivanja učenika u praksu (Lilek, 2018). Povijesni prikaz Centar usmjernog obazovanja „Braće Ribar“ iz općine Đakovo ukazuje na neuspjeh reforme u vidu naznaka niskog životnog standarda u cijeloj zajednici, što se odrazilo na Centar usmjerenog obrazovanja u kojem su idealizirani planovi utopijskog karaktera rezultirali neuspjehom (Rotim, 2015).

Važno obilježje Šuvarovih stavova o reformi obrazovanja uključuje uvjerenje da školsku reformu mora nositi tvrtka kao simbol za sav udruženi rad i za sve što nije obrazovanje, što podrazumijeva ne samo tvornicu kao jedinicu materijalne proizvodnje, već i bilo koji dio društvenog rada. Dakle, prema Šuvaru, tvornica mora diktirati reforme jer sama škola to nije u stanju, škola se ne može sama transformirati i promijeniti u temeljnom, dubokom smislu (Šuvar, 1977, 111). Također, isti autor ističe da sadržaj reforme usmjerenog obrazovanja treba proizlaziti iz aktualnih potreba. Obje karakteristike ove reforme ukazuju na važnost vanjskih i neakademskih čimbenika iz okruženja na tada aktualnu reformu obrazovanja koja je pokušala riješiti socijalne probleme. Također, Jarić $(2012,216)$ s povijesne distance ističe da se Šuvarova reforma temeljila na najmanje dvije unutarnje proturječnosti koje su pridonijele nastanku sistemske disfunkcije, prema kojoj se ta obrazovna reforma najčešće pamti unutar javnog diskursa.

Prva proturječnost je ekonomska i povezana je sa strukturom socijalističkog ekonomskog sustava. U tom je okviru pozivno obrazovanje imalo smisla samo u uvjetima visoko diferenciranog i visoko konkurentnog ekonomskog sustava, a paradoksalno je da je reforma trebala biti provedena u uvjetima nedovoljno razvijenog tržišnog i nedovoljno autonomnog ekonomskog sustava (Jarić, 2012). Druga proturječnost je ideološke prirode i povezana je s ideološkim očekivanjima sustava i Partije oko sadržaja nove kvalitete obrazovanja koju bi reforma trebala promicati (Jarić, 2012, 216). S jedne strane, cilj je bio ojačati i legitimirati određene razvojno-idejno-ideološke i klasne prioritete socijalističke federativne $i$ samoupravne države. S druge strane, naglašavalo se da reformirano obrazovanje treba stvoriti preduvjete za stvaranje „novog građanina“ za novo jugoslavensko socijalističko federalno i samoupravno društvo koje je slobodno, neovisno i osposobljeno da autonomno razmišlja o raznim društvenim i povijesnim problemima i procesima, umjesto da se pasivno konformira i priklanja dominantnim društvenim, političkim i povijesnim globalnim konstrukcijama, okolnostima i procesima (Jarić, 2012).

Drugi kritički pristup Šuvarovoj reformi, možda najistaknutiji i najrelevantniji s gledišta pedagogije, podrazumijeva redukciju humanističkog obrazovanja na štetu proizvodnje, koja deintelektualizira školu s ciljem podređivanja potrebama proizvodnje kako ističe doajen hrvatskog školstva Rosanić (Lilek, 2018). Šuvar je imao ideju da ukine razlike između intelektualnog i manualnog, škole i tvornice i tamo je doživio veliki otpor. Anali- 
zirajući položaj humanističkog obrazovanja kojemu se danas pridaje sve manje važnosti, potrebno je imati na umu Šuvarovo opažanje da se danas ne može smatrati nepismenim samo čovjek koji ne zna dobro čitati i pisati i koji nije upoznat s osnovnim crtama nacionalne i svjetske književnosti, čovjek koji nije stekao znanje filozofije, jezika, povijesti, kao ni opća znanja prirodnih i matematičkih znanosti. Nepismena osoba je i ona koja ne poznaje osnove tehnike i tehnologije i ne ovladava osnovnim tehničkim vještinama potrebnim u svakodnevnom životu. lako sociolog po struci, Šuvar je zagovarao koncept koji je humanističku ulogu obrazovanja stavio u pozadinu i stvari sveo na školu i tvornicu, što je bila aktivna krilatica. Upravo iz tog razloga, odluka o izjednačavanju srednjih i strukovnih škola doživjela je veliki otpor u humanističkim znanostima, kako Rosanić ističe (Lilek, 2018).

Međutim, aktualizacija strukovnog obrazovanja postaje sve značajnija u okviru suvremene bolonjske reforme obrazovanja, što je rezultiralo idejom povezivanja tih reformi. Aktualna bolonjska reforma podjednako je kritizirana kao i neuspješna reforma Šuvara. Kritičari bolonje predviđaju da bi ta reforma mogla završiti kao „šuvarica“. lako je glavna razlika između ovih reformi razina obrazovanja na koju se one odnose, važno je naglasiti da iako je Šuvarova reforma obrazovanja prvenstveno bila usmjerena na srednjoškolsko obrazovanje, njegova koncepcija podrazumijevala je i implikacije za visoko obrazovanje. U tom okviru Šuvar ističe da bi se studenti uključivali u visoko obrazovanje nakon što su po završetku srednje škole dobili posao, a tek potom ih udruženi rad upućuje na fakultete, što je povezano s potrebama. lako to nije dominantno polje istraživanja, Šuvar $(1977,106)$ piše o važnosti udruženog rada u visokom obrazovanju. $U$ tom kontekstu ističe da nije dovoljno uspostaviti izravne veze između „korisnika“ njegovih usluga i njega u smislu izravne i neizravne razmjene rada, niti je dovoljno osuvremenjivanje nastavnih planova i programa, kao i nastavnih metoda, studija i sadržaja te organizacije znanstvenog istraživanja. Kao presudno, Šuvar (1977) ističe prijenos obrazovnog procesa i istraživačkog rada što je više moguće na lice mjesta, tvornice, velike organizacije udružene radne snage, kako u materijalnoj proizvodnji, tako i u društvenim aktivnostima. Jedan od najkontroverznijih zahtjeva je da, osim u iznimnim prilikama, ne treba dolaziti na sveučilište premještanjem „iz klupe u klupu“, već premještanjem s radnog mjesta bilo gdje u zajedničkom radu na radno mjesto na sveučilištu. Najznačajnija implikacija ovog zahtjeva podrazumijeva da odabir za studij vrši tvornica, a ne škola, upis na studije u skladu s ovim razumijevanjem diktiraju potrebe radnog mjesta, a ne potrebu za stjecanjem diplome, studijski program proizlazi iz programa tehničkog i društvenog razvoja za koje određeno istraživanje „proizvodi“ visoko obrazovani stručni i znanstveni kadar (Šuvar, 1977).

U cjelini, kad je riječ o problemima utvrđivanja ciljeva visokog obrazovanja kako im pristupa Šuvar, osnova visokog obrazovanja bez obzira na društveni sustav i razine znanstvenog i tehnološkog razvoja pojedinih zemalja može se definirati u sljedećih pet ciljeva (Šuvar, 1977, 101):

1) širenje visokog obrazovanja kako bi što veći broj ljudi stekao visoko obrazovanje i na toj osnovi obavljao određenu profesiju i stekao određeno mjesto u radnim sustavima i određeni položaj u društvu;

(2) dostupnost visokog obrazovanja sve većem broju ljudi - bez obzira na klasu, socijalnu pripadnost i teritorijalnu distribuciju;

(3) postizanje sve veće razine specijalističkih znanja i vještina temeljenih na jedinstvu obrazovnog procesa i znanstvenog rada u visokom obrazovanju; 
(4) povezivanje visokoškolskih aktivnosti s gospodarstvom i drugih djelatnosti i njihovo stavljanje u funkciju njihova razvoja;

(5) razvijanje visokog obrazovanja za one koji već rade i koji se moraju kontinuirano obrazovati. Gore navedeni ciljevi usklađeni su sa suvremenim zahtjevima za demokratizacijom visokog obrazovanja, suvremenim zahtjevima za specijalizacijom, zahtjevima za uvođenjem dualnog obrazovanja u visoko obrazovanje, kao i sa zahtjevima za permanentnim obrazovanjem. Svi se ti ciljevi potiču u okviru Bolonjskog procesa obrazovanja.

Druga osnova za povezivanje Šuvarove i bolonjske reforme proizlazi iz izjave istaknutog hrvatskog sociologa (Pilić) koji ističe da se tadašnja reforma temeljila na funkcionalističkom konceptu utemeljenom na potrebi zajedničkog rada. U tom kontekstu, zalažući se za udruženi rad i obrazovanje, Šuvar (1977) ističe da se bitka za duboku transformaciju odgoja i obrazovanja može dobiti samo unutar cjelokupne transformacije tvornice i škole, spajanjem njihovih funkcija i na tragu stvaranja odnosa i svijesti svojstvenih društvu udruženog rada. Također, isti autor ističe da je potrebna međusobna otvorenost tvornice i škole, ali na način da tvornica ne upravlja školama, niti da škola proizvodi one koji će upravljati radnicima u tvornici. Umjesto odnosa podređenosti i superiornosti, Šuvar se zalaže za timski rad kako bi mogao izraziti svoje obrazovne potrebe i da škola može zadovoljiti te obrazovne potrebe sa svojim obrazovnim programima. Danas se govori o potrebi povezivanja škola i gospodarstva - nije li to još funkcionalnije, pita Pilić (prema: Lilek, 2018)? Sve više se ističu zahtjevi za razvojem poduzetništva u okviru procesa obrazovanja na različitim stupnjevima obrazovanja. Kako bi se spriječile negativne implikacije, ali ne i odbacila važnost ove teme, neizbježan je analitički i kritički pristup predstavnika akademske zajednice. Mnogo je kritičara bolonjskog procesa. U tom se kontekstu, između ostalog, ističe (Rončević i Rafajac, 2010, 26) da provedba Bolonjskog procesa podrazumijeva političku odluku na najvišem nivou, bez prethodnog uključivanja dijaloga s akademskom zajednicom, što je rezultiralo da su visokoškolske institucije bile prisiljene započeti s provedbom. Uzelac (2007) također oštar kritičar Bolonjskog procesa, postavlja sljedeće pitanje: Koji su stvarni i istinski razlozi kolapsa postojećeg obrazovnog sustava u vrijeme kada obrazovanje dobiva na sve većoj važnosti, a neka „znanja“ sve većom brzinom postaju zastarjela? Sheme predmetno organiziranih znanja, koje nastavnici predaju učenicima u posebnim obrazovnim ustanovama, znanja kakva poznaje tradicija malo je povezano s potrebama tržišta rada i trendovima u razvoju obrazovnih sustava. Jedan od najvećih kritičara Bolonjskog procesa je Konrad Paul Liessmann (Liessmann, 2008), koji govori o povijesnom razvoju obrazovanja u kontekstu prelaska iz teorije obrazovanja, preko teorije polu-obrazovanja u naše vrijeme i teorije neobrazovanosti, upravo u društvu znanja u kojem se znanje najmanje cijeni iako je formalno glorificirano. Bodroški Spariosu (2017) ukazuje na izazove s kojima se moderno sveučilište suočava, prije svega kao posljedicu uvođenja Bolonjskog procesa, postavljajući pitanje podrazumijeva li implikacija Bolonjskog procesa novu filozofiju obrazovanja ili čisti proračun, bez filozofije?

Slično kao kod Šuvara, bolonjska reforma teži što bržem zapošljavanju na tržištu rada. Činjenica da je Šuvarova reforma podrazumijevala srednje obrazovanje, dok se bolonjska reforma odnosi na visoko obrazovanje, koje značajno degradira obrazovanje na najvišoj razini. Kao što Laušević (2010) ističe, dominantni normativni pojmovi reforme visokog obrazovanja su: standardi, planiranje, učinkovitost, umrežavanje, kontrola. Sam norma- 
tivni vokabular, osim nastojanja da se regulira i ujedini sveučilišni prostor i postignu minimalni potrebni uvjeti, ima i svoju drugu stranu. Ta je strana implicitno prisutna u težnji da se sveučilište stavi pod kontrolu i stalni nadzor izvan sveučilišnih instanci. To isključuje čuvenu autonomiju sveučilišta, odredbu koja je u osnovi definira sveučilišta kao institucije utemeljene na slobodi poučavanja i znanstvenog istraživanja. Autonomija sveučilišta postaje ironična primjedba o onome što u stvarnosti ne postoji. Umjesto autonomije i samokontrole, sveučilišta se sada nameću kontrolom, što dolazi od politike, od donatora, od primatelja sveučilišnih usluga, s tržišta znanja i obrazovanja.

Ukoliko kritici pristupimo na komparativnoj osnovi, u odnosu na Šuvarovu reformu i okvir bolonjske reforme obrazovanja, značajne kontradikcije su i ekonomske i ideološke prirode. Podređenost obrazovnog procesa tržištu, kao i ideološka i politička podjela između prijatelja i neprijatelja Bolonje, reformista i tradicionalista, europljana i antieuropljana (Laušević, 2010) te ukazuju na to da značajne promjene u funkcioniranju sveučilišta donose vanjski utjecaji čiji su interesi prije svega socio-ekonomski i politički. Analizirajući različite probleme s kojima se moderna sveučilišta suočavaju u okviru moderne reforme visokog obrazovanja, značajan problem predstavlja činjenica da su moderna sveučilišta usmjerena na razvoj korisnih kompetencija, kompetencija koje su korisne gospodarstvu, čime ubijaju interes mladih za sve što se ne može prodati (Vuletić , 2009 prema: Rončević i Rafajac, $2010,27)$. Upravo u tome Vuletić smatra da je osnovni apsurdnost reforme: bez obzira na to što se profesije i tržište rada mijenjaju alarmantnom brzinom, sveučilište je dužno pripremiti stručnjake specijalizirane za vrlo specifične zadatke. Vuletić definira nelogičnosti zahtjeva unutar bolonjske reforme postavljajući sljedeća pitanja: Ne bi li visokoobrazovana osoba koja je sposobna rješavati apstraktne probleme, navikla na intelektualni rad u najširem smislu, bila korisnija društvu u takvim uvjetima? Ne bi li društvu bolje došli takvi intelektualci, koji bi se onda lako obučili za bilo koji određeni zadatak u takvoj tvrtki? Vuletić se također pita nije li vrhunski intelektualac i humanist najbolji proizvod koji se može zamisliti (Vuletić, 2009. prema: Rončević i Rafajac, 2010)?

\section{Tabela 1. Sličnosti i razlike bolonjske i Šuvarove reforme obrazovanja}

\begin{tabular}{lll}
\hline & Bolonjska reforma & Šuvarova reforma \\
\hline \multirow{3}{*}{ sličnosti } & $\begin{array}{l}\text { značaj utjecaja vanjskih društveno ekonomskih činioca } \\
\text { povezane sa svijetom rada i zahtjevima tržišta } \\
\text { manji značaj humanističke dimenzije } \\
\text { često kritizirane } \\
\text { veći utjecaj socijalnih u odnosu na obrazovne ciljeve }\end{array}$ & \\
razlike & $\begin{array}{l}\text { aktualna } \\
\text { visokoškolsko obrazovanje }\end{array}$ & nije više aktualna \\
& & srednjoškolsko obrazovanje \\
\hline
\end{tabular}

Na osnovi proučene literature u Tabeli 1. predstavljene su osnovne sličnosti i razlike Šuvarove i bolonjske reforme i one ukazuju na značaj društveno-ekonomskih utjecaja na proces obrazovanja. U tom kontekstu u cilju sveobuhvatnog pristupa obrazovanju od sve većeg značaja je proučavanje vanjskih čimbenika koji sve učestalije određuju smjer razvoja obrazovanja. 


\section{ZAKLJUČNE NAPOMENE}

Činjenica je da se na obrazovni proces oduvijek gledalo kao na značajan segment koji potiče razvojne procese u društvu. U skladu s rastućim društvenim promjenama koje su rezultirale potrebom za povećanjem broja visokoobrazovanih stručnjaka, nije iznenađujuće da je poseban naglasak stavljen na reformu visokog obrazovanja. Međutim, na važnost opreza prilikom uvođenja novih reformi ukazuju brojne kritike. Sličnosti predstavljene između Šuvarove i bolonjske reforme obrazovanja ukazuju na to da se u reforme često ulazi brzo te da vanjski društveno-ekonomski čimbenici, iako imaju velik utjecaj na obrazovni proces, prenaglašavaju socijalne u odnosu na obrazovne ciljeve.

Najveći problem suvremenih reformi ukazuje na sve veće prodiranje tržišnih mehanizama u obrazovne procese koji negativno utječu na društvene i humanističke znanosti. Brojne kritike suvremenog obrazovanja (Bok, 200; Liessmann, 2008) ukazuju na važnost obrađivanja ove teme. Kad je u pitanju odnos škole i tvornice, Šuvar $(1977,5)$ ističe da je najvažnije ponuditi odgovore na tri pitanja: kakav je odgoj i kakvu vrstu i koliko obrazovanje trebaju steći (svi) članovi društva; kakvo je obrazovanje potrebno za rad i život i kakva bi trebala biti veza između rada i obrazovanja. Upravo s tim pitanjima i njihovim odgovorima razmatra se društvena funkcija obrazovanja. Ako se napravi paralela s Bolonjskim procesom i reformom visokog obrazovanja, ta su pitanja još uvijek aktualna, a nezadovoljavajući učinci Šuvarove reforme mogu poslužiti kao dobro polazište tako da bolonjska reforma visokog obrazovanja, koja je već poprimila mnoge negativne konotacije, ne bi ostala zapamćena kao Šuvarova. Šuvar (1977) ističe da u 18. stoljeću nastaje tzv. industrijska pedagogija, koja više izražava potrebu buržoazije za homo oeconomicusom nego brigom za homo faber-a, koja objašnjava da je cilj bio stvaranje psihološke klime ekonomije, koja je neophodna za kapitalistički način proizvodnje. Drugim riječima, u toj fazi društvenoproduktivnog razvoja potrebno je više ekonomskog obrazovanja nego tehničkog obrazovanja (Šuvar, 1977, 8). U tom kontekstu, čak i danas, upravo zato što se tržišna orijentacija visokog obrazovanja često kritizira, to ukazuje i na njenu rastuću prisutnost, čak i kao neizbježnu pojavu čije je znanje i razumijevanje važno kako bi se umanjile negativne posljedice. Usporedba Šuvarove i Bolonjske reforme ukazuje na važnost povijesne dimenzije, kao i na činjenicu da brojne obrazovne reforme, iako su se pokazale kao neuspješne u sličnim oblicima, ponovno dobivaju na značaju samo na drugom stupnju (umjesto srednjeg visoko obrazovanje) ne kao zahtjev akademske, nego društvene zajednice.

Predstavnici akademske zajednice nedovoljno poznaju ovu tematiku, prije svega sveučilišni nastavnici i studenti, te to sprječava sveobuhvatan pristup razumijevanju složenih i kontroverznih uvjeta u kojima se obrazovne institucije nalaze, kao i povećanog broja zahtjeva koji se postavljaju pred obrazovne institucije. Kao što je Šuvarova reforma isticala srednjoškolsko obrazovanje jer je u to vrijeme bila od posebnog značaja za društvo, tako se i sada, unutar gospodarstva utemeljenog na znanju, Šuvarove ideje s mnogim sličnostima prenose u visoko obrazovanje. 


\title{
SIMILARITIES AND DIFFERENCES OF SUVAR'S AND BOLOGNA EDUCATION REFORMS
}

\author{
Maja Bosanac, research associate \\ University of Novi Sad \\ Address: Dr Zorana Đinđića 2, Novi Sad, Serbia \\ Phone: 00381649309637, e-mail: maja.bosanac@ff.uns.ac.rs \\ Radovan Grandić, retired professor \\ University of Novi Sad \\ Address: Dr Zorana Đinđića 2, Novi Sad, Serbia \\ Phone:0038163507398,e-mail: grandic@neobee.net
}

\begin{abstract}
Upbringing and education have always been inextricably linked with social, economic, political and cultural events. The aim of the paper is to consider the basic similarities and differences between Bologna and Suvar's education reforms. Although Bologna reform is aimed at higher education and Suvar's reform primarily refers to secondary education, these reforms have many similarities that can be significant when it comes to getting a more comprehensive understanding of the numerous expectations placed upon modern educational institutions. One of the basic similarities of both reforms is the connection of education with the world of work and market demands. It is precisely this characteristic of contemporary requirements that is set in front of education and is at the same time the most controversial and often criticized. The contribution of the paper implies the actualization of the issue of Suvar's reform, which is often compared to the Bologna Process. The paper concludes that, regardless of the differences and the fact that Suvar's reform was abandoned in contrast to the current Bologna, a comparison of these reforms may be important, especially when it comes to understanding the impact of socio-economic and political influences on the education process.
\end{abstract}

Keywords: education reform; Bologna Process; Suvar's reform; directed education; market 


\section{LITERATURA}

1. Bodroški-Spariosu, B. (2015). Univerzitetsko obrazovanje-od Humboltovog modela do Bolonjskog procesa. Nastava i vaspitanje, 64(3), 407-420.

2. Bodroški Spariosu, B. (2017). Univerzitetsko obrazovanje pred stalnim izazovima. Beograd: Institut za pedagogiju i andragogiju Filozofskog fakulteta Univerziteta u Beogradu.

3. Bok, D. (2005). Univerzitet na tržištu. Beograd: Clio.

4. Dimitrijević, S. (2009). "Bolonja“ kao „šuvarica“. Preuzeto s: http://www.politika.rs/sr/ clanak/82134/Bolonja-kao-suvarica. (26.05.2020.)

5. Gibbons, M. (2000). Mode 2 society and the emergence of context-sensitive science. Science and public policy, 27(3), 159-163.

6. Grandić, R. (2007). Prilozi uvodu u pedagogiju. Novi Sad: Savez pedagoških društava Vojvodine.

7. Grandić, R., Bosanac M., (2019). Uticaj nove produkcije znanja na savrmene univerzitete. Inovacije u nastavi, 32(3), 39-51.

8. Jarić, I. (2012). Srednjoškolska nastava sociologije u periodu usmerenog obrazovanja. Sociološki pregled, 46(2), 215-234.

9. Liessmann, K. P. (2008). Teorija neobrazovanosti: zablude društva znanja. Zagreb: Jesenski i Turk.

10. Lilek, M. (2018) Zazivanje Šuvara: Kako je njegova reforma postala aktuelna danas. Preuzeto s: https://www.jutarnji.hr/globus/Globus-politika/zazivanje-suvara-kako-je-njegova-reformapostala-aktualna-danas-on-je-uveo-model-skolovanja-za-potrebe-privrede-a-danasnji-reformatori-traze-slicno/7175487/ (26.05.2020.)

11. Milutinović, J. (2008). Ciljevi obrazovanja i učenja u svetlu dominantnih teorija vaspitanja $20.0 g$ veka, Novi Sad: Savez pedagoških društava Vojvodine.

12. Pejanović, R. (2019). Izazovi ekonomskog obrazovanja. Novi Sad: Akademska knjiga.

13. Pilić, Š. (2005). In memoriam: Stipe Šuvar (1936.-2004.). Revija za sociologiju, 36(3-4), 225-229.

14. Rončević, N., Rafajac, B. (2010). Promjene u akademskoj profesiji: komparativna analiza. Rijeka: Filozofski fakultet u Rijeci.

15. Rotim, M. (2015). Rad Centra usmjerenog obrazovanja „Braće Ribar “iz Đakova u 1980-im. Zbornik muzeja Đakovštine, 221-236.

16. Šuvar, S. (1977). Škola i tvornica. Zagreb: Školska knjiga.

17. Uzelac, M. (2007). Metapedagogija. Vršac: Visoka strukovna škola za obrazovanje vaspitača Vršac. 